\title{
A Case $\mathbf{S}_{\text {tudy }}$ Trends in production and export of wheat in India
}

\section{TOYIN ADERONKE OLADELE AND DENIS MAGNUS KENAMARA}

See end of the paper for authors' affiliations

Correspondence to : TOYIN ADERONKE OLADELE

Department of Agricultural Economics, College of Agriculture, University of Agricultural Sciences, DHARWAD (KARNATAKA) INDIA

Email: toyaderon.2013@gmail. com

\section{Paper History :}

Received : 18.07.2014;

Accepted : 15.02 .2015
ABSTRACT : The study examined the trends in area, production and yields of wheat in India over the period of 1970-12 and ascertained the status of India in the world market of production and export of wheat from 1996-12. Data were collected from the official website of FAO and "Land use statistics" (India) and analyzed using mean, compound growth rates and instability index. The results revealed that the annual growth rates in production and yield of wheat increased significantly during the pre-WTO period but had dropped marginally during the post-WTO. The post-WTO period on the other hand had shown a recognizably least instability index in area, production and yield of wheat but yield had shown higher instability in the overall and pre-WTO periods. On overall, India had shown a significant growth in the production of wheat but had fallen short in export market. The compound growth rate in the export over the selected period showed a very high negative growth rate as well as instability index in both export and import markets.

KEY WORDS : Wheat, Production, Compound growth rate, Instability index, WTO

HOW TO CITE THIS PAPER : Oladele, Toyin Aderonke and KenAmara, Denis Magnus (2015). Trends in production and export of wheat in India. Internat. Res. J. Agric. Eco. \& Stat., 6 (1) : 189-192. 